\title{
Activated Protein C Resistance Measurement
}

National Cancer Institute

\section{Source}

National Cancer Institute. Activated Protein C Resistance Measurement. NCI Thesaurus.

Code C100471.

A measurement of the resistance in the anticoagulation response to activated protein C in a biological specimen. 